Int. J. Dev. Biol. 59: 131-140 (2015)

doi: $10.1387 / \mathrm{ijdb} .150061 \mathrm{pa}$

\title{
Immunogenic cell death
}

\author{
ABHISHEK D. GARG, ALEKSANDRA M. DUDEK-PERIC, ERMINIA ROMANO and PATRIZIA AGOSTINIS* \\ Cell Death Research \& Therapy (CDRT) Laboratory, Department for Cellular and Molecular Medicine, KULeuven \\ University of Leuven, Leuven, Belgium
}

\begin{abstract}
Currently, it is widely acknowledged that a proactive anticancer immunosurveillance mechanism takes part in the rejection of neoplastic lesions before they progress towards a benign or malignant tumour. However in cases of very aggressive neoplastic lesions consisting of cells with high mutational diversity, cancer cell variants might be formed that are capable of evading host defence systems against uncontrolled proliferation and anticancer immunosurveillance. This is mainly accomplished through the exhibition of low immunogenicity, which is a particularly important stumbling block in the revival of long-lasting as well as stable anticancer immunity. Recently, it has emerged emphatically that inciting a cancer cell death routine, associated with the activation of danger signalling pathways evoking emission of damage-associated molecular patterns (DAMPs), markedly increases the immunogenicity of dying cancer cells. This cell death pathway has been termed "immunogenic cell death" (ICD). In the present review we introduce this concept and discuss its characteristics in detail. We also discuss in detail the various molecular, immunological and operational determinants of ICD.
\end{abstract}

KEY WORDS: immunogenicity, immunogenic cell death, cancer, danger signals, antigen, damage-associated molecular patterns, danger signalling, ER stress, photodynamic therapy (PDT), chemotherapy

\section{Immunogenic cell death: the concept}

Most newly formed neoplastic lesions in our body are readily rejected by the host defence system. It is now widely acknowledged that a proactive anticancer immunosurveillance mechanism takes part in rejection of neoplastic lesions before they progress towards a benign or malignant tumour (Dunn et al., 2002, Senovilla et al., 2012). However in cases of very aggressive neoplastic lesions consisting of cells with high mutational diversity; cancer cell variants might be formed that are capable of evading host defence systems against uncontrolled proliferation and anticancer immunosurveillance (Dunn et al., 2002, Zitvogel et al., 2006). In such a scenario, the host immune system might start acting as a "natural selection force" by performing cancer immunoediting, which might lead to the formation of cancer cells that are highly immunoevasive and capable of resisting antitumour immunity (Dunn et al., 2002). Overall resistance against the host anticancer immunosurveillance and antitumour immunity is achieved by various mechanisms including, acquaintance of low immunogenicity, ability to induce immunotolerance or active immunosuppression, and ability to resist immune cell-mediated lysis (Dunn et al., 2002, Garg et al., 2013b, Zitvogel et al., 2006). Here, the exhibition of low immunogenicity is a particularly important stumbling block in the revival of long-lasting as well as stable anticancer immunity. Therefore it had been proposed recently that, one route through which one can revive potent anticancer immune responses, is by accentuating the general immunogenicity of cancerous cells (Casares et al., 2005). Research published over the last decade has established that spatiotemporally defined emission of danger signals or damageassociated molecular patterns (DAMPs) as a part of an elaborate danger signalling module can help in elevating the immunogenicity of dying, stressed or dead cancer cells - a concept pioneered by the labs of Guido Kroemer and Laurence Zitvogel (Kroemer et al., 2013). Operationally, it has been shown that inciting a cancer cell death routine, associated with the activation of danger signalling pathways evoking the pre-mortem emission of DAMPs, markedly increases the immunogenicity of these dying cells (Kepp et al., 2014). This cell death pathway has been termed as 'immunogenic

\footnotetext{
Abbreviations used in this paper: ATP, adenosine triphosphate; CD, cluster of differentiation; CAAs, cancer associated antigens; CRT, calreticulin; DAMP, damageassociated molecular pattern; DC, dendritic cell; DNA, deoxyribonucleic acid; ER, endoplasmic reticulum; HSP, heat shock protein; Hyp, hypericin; ICD, immunogenic cell death; IFN, interferon; IL, interleukin; PDT, photodynamic therapy; TAAs, tumour-associated antigens; TLR, toll-like receptors; TNF, tumour necrosis factor; UPR, unfolded protein response.
} 
Fig. 1. The activity of Type I and Type II immunogenic cell death (ICD) inducers. Type I ICD inducers are modalities that induce cell death via non-ER associated targets and danger signalling via ER stress; however this split in targeting might compromise their ability to fully target the ER (site of off-target/collateral effects). On the other hand, Type II ICD inducers selectively target the ER to induce both cell death as well as danger signalling thereby causing ICD-associated immunogenicity in an ER-focused (on-target) manner. 7A7, antiepidermal growth factor receptorantibody; CGs, cardiac glycosides; CTX, cyclophosphamide; DOXO, doxorubicin; HHP, high hydrostatic pressure; Hyp-PDT, hypericin-based photodynamic therapy; IRR, iradiation (radiotherapy); MTA, microwave thermal ablation; MTX, mitoxantrone; OXP, oxaliplatin; PAT, patupilone; RLH-L, RIG-I-like helicase ligand; Sep, septacidin; UVC, UV radiation, C-band.
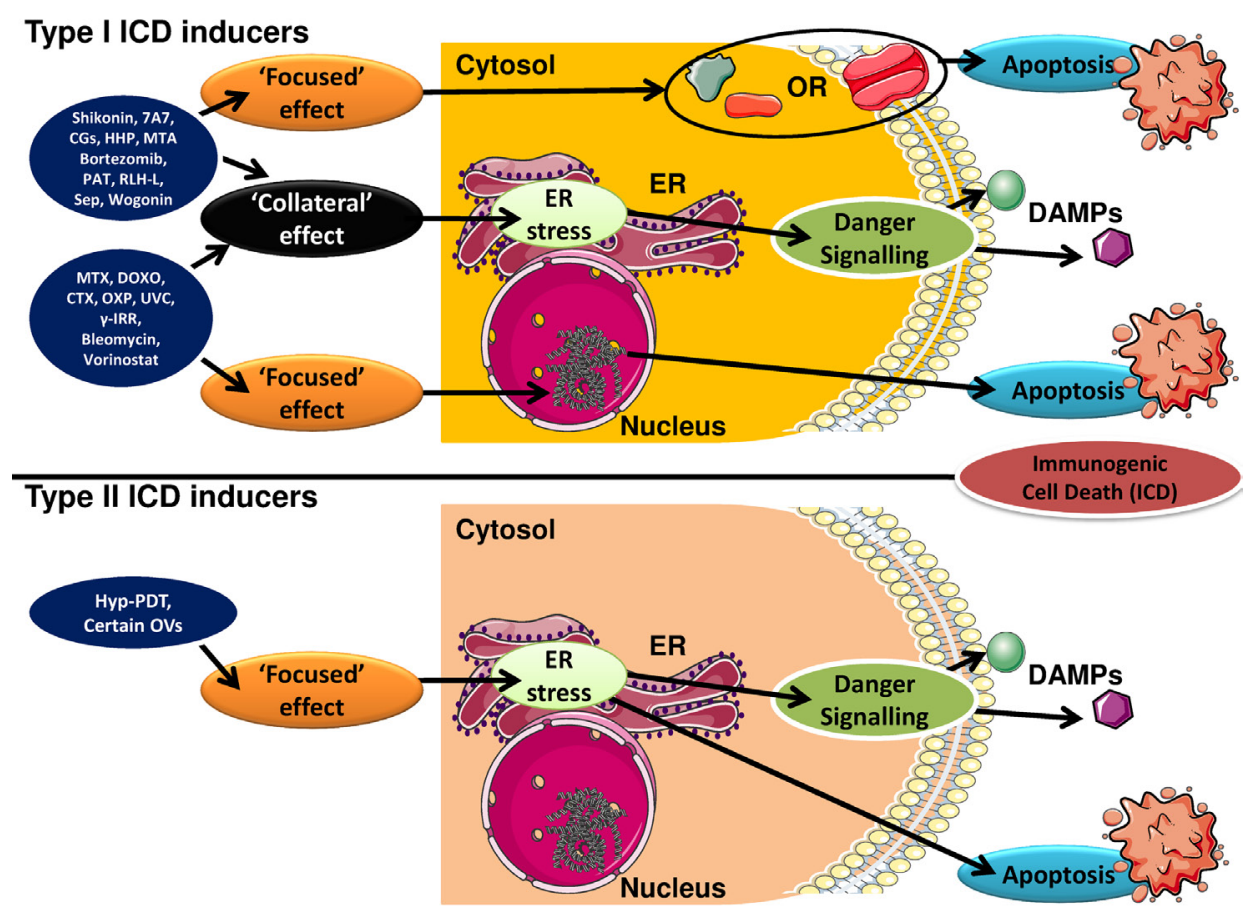

cell death (ICD)' (Kepp et al., 2014; Kroemer et al., 2013; Garg et al., 2014). ICD has the ability to convert dying or dead cancer cells into a "vaccine" capable of inducing anticancer immunity in absence of any additional adjuvants (Galluzzi et al., 2014).

ICD is highly stressor-dependent (Fig. 1) primarily because its execution requires elicitation of oxidative-endoplasmic reticulum (ER) stress (Garg et al., 2012c), or at least almost simultaneous induction of reactive oxygen species (ROS) and ER stress (Panaretakis et al., 2009). The concomitant induction of oxidative stress and ER stress is crucial for elicitation of danger signalling pathways mediating the trafficking and emission of danger signals or DAMPs (Galluzzi et al., 2012, Garg et al., 2012c). The first systematic screening for ICD inducers (Obeid et al., 2007) recognised, anthracyclines, mitoxantrone, and radiotherapy (Fig. 1), as potent inducers of ICD in cancer (Box 1). Since this screening study, other novel and highly efficacious ICD inducers have been identified by targeted studies (Fig. 1), which include various assorted chemotherapeutics, certain targeted therapeutics, various physical modalities, certain components of Chinese traditional medicine, certain oncolytic viruses and hypericin-based photodynamic therapy (Hyp-PDT) (Box 1). However, some inducers in this list, such as mitoxantrone, Hyp-PDT, shikonin, cardiac glycosides and bortezomib, have unique properties that make them 'near-to-ideal' inducers of ICD (Krysko et al., 2012). Importantly, Hyp-PDT is the first ever ICD inducer shown to specifically target the ER via oxidative stress (in a 'focused', on-target manner) thereby inducing a molecularly superior form of ICD, both in terms of kinetics as well as mechanics of danger signalling (Garg et al., 2012c, Krysko et al., 2012). On the other hand, mitoxantrone is currently the most studied ICD inducer, in terms of both extensive in vivo immunological knowledge about its anticancer activity and its clinical immunostimulatory activity (Kepp et al., 2014). Mitoxantrone (or anthracyclines in general) has played an important role in characterizing the mechanics and kinetics of ICD (Kroemer et al., 2013, Krysko et al., 2012). But it is expected that as more ICD inducers are discovered, we would learn more about ICD, its complexity and whether certain danger or immunological signalling processes are broadly applicable to ICD or ICD inducer-specific.

Of note, the pioneering (as well as a large portion of the followup) research on ICD characterized it largely as an apoptotic yet immunogenic form of cell demise (Casares et al., 2005, Obeid et al., 2007). However, it has now started to emerge that another programmed form of cell death i.e. programmed necrosis or necroptosis may also associate with ICD. More specifically, it has been recently shown that Newcastle disease virus (NDV) can induce ICD that is necroptotic in nature (since NDV-induced ICD is devoid of apoptotic features, yet is programmed, and can be inhibited by Necrostatin-1) (Koks et al., 2015). However the exact molecular pathways behind this NDV-induced necroptotic ICD still need further attention. Interestingly, NDV is so-far the only known ICD-inducing oncolytic virus (Koks et al., 2015) to exhibit the property of inducing "abscopal effect"-like anti-tumour immunity (i.e. anticancer immune response-based regression of distant tumour sites without gaining direct, physical, contact with these sites) (Zamarin et al., 2014). It would be interesting to see in future, if other programmed cell death routines like mitotic catastrophe, anoikis, paraptosis, pyroptosis and entosis can also be associated with ICD.

Last but not least, as a simple structure-function relationship for ICD inducers is virtually non-existent (and perhaps impossible), we had proposed a classification scheme for all the ICD inducers. This scheme is based on the ability of an ICD inducer to target the ER and to induce as many ICD-relevant processes (e.g. cell death and danger signalling) as possible, through ER stress (Fig. 1). As per this scheme, the ICD inducers can be classified as Type I and Type II (Dudek et al., 2013, Garg et al., 2014, Krysko et al., 2012) (Fig. 1; Box 1). Here, Type I ICD inducers are modalities 
that induce cell death via non-ER associated targets and danger signalling via ER stress (Fig. 1); however this split in targeting might compromise their ability to fully target the ER (site of off-target/ collateral effects) thereby compromising their ability to fully exploit ER stress-based danger signalling (Fig. 1). Most of the known ICD inducers fall under the category of Type I ICD inducers (Box 1) such that they cause cancer cell death by acting on non-ER associated targets like DNA/chromatin or DNA replication and repair machinery proteins, certain cytosolic proteins, mitochondria, various cellular membranes and certain surface transmembrane proteins/ channels (Fig. 1). On the other hand, Type II ICD inducers (Box 1) selectively target the ER to induce both cell death as well as danger signalling thereby causing ICD-associated immunogenicity in an ER-focused (on-target) manner (Fig. 1) (Dudek et al., 2013, Garg et al., 2014, Krysko et al., 2012). In fact, using our theory of Type I/II ICD inducers, a group of researchers recently characterized a new Type II ICD inducing chemotherapeutic compound, PtII Nheterocyclic carbine complex, based on this compounds' affinity with the ER (Wong et al., 2015). This clearly shows that the Type I/II ICD inducer concept can be exploited for discovery of new ICD inducers based on their preferential targeting of the ER.

Although therapeutically advantageous on many levels, the emergence of ICD has been full of controversy. While on one hand it has been described by some as a bystander effect yet others have raised doubts on its human applicability, pointing it out to be a majorly rodent-associated phenomenon. In fact recently ICD was reported to be non-existent in a spontaneous mice model (Ciampricotti et al., 2012). More specifically, it was shown that in a set-up of spontaneous mammary cancer model, the anticancer efficacy of both ICD or non-ICD inducers could not be differentiated; in both immunocompetent as well as immunodeficient backgrounds thereby raising doubts on ICD existence (Ciampricotti et al., 2012). However, one must remember that many major determinants of cancer immunogenicity had been initially dismissed as nonexistent (due to controversial or contradictory results) only to be later established as bona fide entities owing to reporting of strong supportive data. The best example of this is, ironically, cancerassociated antigens (CAAs) or tumour-associated antigens (TAAs) themselves, the very entities that form the foundation of cancer immunology and immunotherapy. Research done between 1940s and 1960s showed that mouse and possibly human cancer cells can be recognized by the immune system (Coulie et al., 2014). However, in stark contrast, a 1976 study using spontaneous cancer models failed to substantiate the role of anticancer immunity and

\section{BOX 1}

SINGLE-AGENT IMMUNOGENIC CELL DEATH INDUCERS [Extended from (Dudek et al., 2013)]

\section{Type I ICD inducers}

\section{Chemotherapeutics or targeted therapeutics/drugs}

Bleomycin* (Bugaut et al., 2013), Bortezomib (Spisek et al., 2007), Cyclophosphamide** (Schiavoni et al., 2011), Doxorubicin, Idarubicin, Mitoxantrone and Epirubicin (Fucikova et al., 2011, Garg et al., 2013a, Garg et al., 2015, Obeid et al., 2007), Oxaliplatin (Martins et al., 2011), Patupilone (Senovilla et al., 2012) Septacidin (Sukkurwala et al., 2014), Shikonin (Chen et al., 2012), Vorinostat (West et al., 2013), Wogonin (Yang et al., 2012) and Paclitaxel (Garg et al., 2015).

\section{Biological therapeutics/agents}

7A7 anti-EGFR antibody (Garrido et al., 2011), RIG-I-like helicases (RLH) Ligand (Duewell et al., 2014) and Clostridium difficile toxin B (Sun et al., 2015).

\section{Physico-chemical or mechanical stress-based therapeutics/agents}

High Hydrostatic Pressure (Adkins et al., 2014, Fucikova et al., 2014), Microwave Thermal Ablation (Yu et al., 2014), Specific forms of Radiation therapy (Galluzzi et al., 2013, Gameiro et al., 2014, Garg et al., 2015, Obeid et al., 2007, Schildkopf et al., 2011) and UVC irradiation (Panaretakis et al., 2009)

\section{Type II ICD inducers}

\section{Hypericin-based photodynamic therapy (Hyp-PDT)}

(Dudek-Peric et al., 2015, Garg and Agostinis, 2014, Garg et al., 2013b, Garg et al., 2012a, Garg et al., 2012b), Pt" N-heterocyclic carbene complex (Wong et al., 2015) and Various Oncolytic Viruses (Kepp et al., 2014, Koks et al., 2015, Pol et al., 2014).

Important notes on ambivalence or exceptions: \#Bleomycin is an ambivalent ICD inducer; it induces all the determinants but paradoxically increases levels of the immunosuppressive Treg cells; * ${ }^{*}$ Cyclophosphamide induces ICD only at metronomic doses; at high doses it can in fact be detrimental to the host immune system in general.

Note on upcoming ICD-inducers: Many anticancer agents or therapies have been recently shown to expose ICD-associated DAMPs like surfaceCRT and/or secreted-ATP and/or released-HMGB1. However in many cases, not all ICD-associated DAMPs are checked. On other occasions, in vitro DAMPs detection is done but proper in vivo vaccination or anti-tumour immunity analysis is absent. In absence of full-analysis on all of the above levels, the agents cannot be classified as bona fide ICD inducers. Please refer to recent guidelines for proper ICD characterization (Kepp et al., 2014). 
concluded that CAAs/TAAs might simply be carcinogen-induced artifacts (Hewitt et al., 1976). Later, more elaborate analysis proved the existence of CAAs/TAAs in murine system (Boon and Kellermann, 1977, Boon and Van Pel, 1978) and also proved that spontaneous mouse tumours are capable of expressing CAAs/ TAAs however they are comparatively poorly immunogenic (Van Pel and Boon, 1982). These developments paralleled or closely followed, the discovery and characterization of T cells in 1960s; and subsequently the indispensable role of $T$ cells in mediating CAA/TAA-specific tumour-rejecting immunity came to be realized between 1970s and 1980s (Coulie et al., 2014). All these efforts culminated into the characterization of the first murine TAA i.e. P91A in 1988 (De Plaen et al., 1988) and the first human TAA i.e. melanoma antigen family A, 1 (MAGEA1) in 1991 (van der Bruggen et al., 1991). Following these initial breakthroughs, a number of CAAs/TAAs have been identified (both in human and murine systems) and these have paved way for more advanced concepts in the fields of cancer immunology and immunotherapy (Coulie et al., 2014). In a very similar fashion, the concept of 'danger signals' or DAMPs, which is innate to the execution of ICD, was also initially dismissed (Pradeu and Cooper, 2012) after being proposed in 1994 (Matzinger, 1994). It was considered highly controversial because it challenged the "self-non-self-theory" of basic immunology stating that an immune response is only triggered against a foreign, nonself-entity but not against an organism's own components (self) (Pradeu and Cooper, 2012). However, since then, the existence of danger signals or DAMPs has been firmly established; thanks to the initial research into the role of heat-shock proteins acting as DAMPs (Pradeu and Cooper, 2012) finally culminating into the currently known scenario of DAMPs associated with necrosis, ICD, inflammatory or immunopathologies and autoimmune diseases.

To this end, based on all the recent supportive data that has been published, the existence of ICD is incontrovertible (Galluzzi et al., 2014, Kepp et al., 2014, Kroemer et al., 2013); however it is perfectly expected, in a complex disease like cancer, that in certain contexts ICD may not happen, either due to defects that inhibit or compromise ICD (e.g. incapability of certain drugs to induce danger signalling via ER stress or mutations/ablations in major danger signalling pathways required for ICD execution) or due to the failure of host system to respond to ICD in its entirety (e.g. due to defects in immune-receptors crucial for ICD sensing or due to natural/drug induced immune-deficiencies) (Garg et al., 2014, Kroemer et al., 2013, Krysko et al., 2012). In fact, we have recently shown that the ICD-resistant phenotype can also stem from low endogenous levels of CRT protein in cancer cells which results in defective surface-CRT levels, which further causes severely reduced phagocytic clearance of treated cancer cells and ultimately leads to the failure of tumor-rejecting immunity (Garg et al., in press).

\section{Emission of danger signals: molecular determinants of immunogenic cell death}

ICD has been found to associate with spatiotemporally defined emission of three categories of danger signals or DAMPs i.e. surface exposed chaperones (exposed in the pre-apoptotic or pre-mortem stage), secreted or released nucleotides/nucleic acids (secreted/ released in pre- or early-apoptotic/mortem stages) and release of endogenous toll-like receptor (TLR) agonists (released in mid- or post-apoptotic/mortem stages) (Zitvogel et al., 2010) (Garg et al., 2014, Kroemer et al., 2013).

\section{Surface exposure of particular chaperones}

Surface exposure (ecto-) of certain intracellular chaperones like calreticulin (CRT), heat shock protein 90 (HSP90) or HSP70 has been found to be crucial for the immunogenicity of dying or dead cancer cells. On the surface of the stressed/dying cancer cells, ecto-CRT has been reported to dock on either lipid rafts or LRP1 in an inducer/context-dependent fashion (Gardai et al., 2005, Garg et al., 2012c), whereas HSP90 tends to bind to LRP1 (Gopal et al., 2011). However, to date not much is known about HSP70's docking preferences; interestingly, though HSP70's relatively consistent surface distribution as patches and/or small clumps suggests that it may not share a docking-entity with ecto-CRT since the latter tends to have a more uneven distribution (Gardai et al., 2005, Garg et al., 2012b, Garg et al., 2012c).

Functionally, these chaperone-DAMPs tend to bind various immune-receptors like, CD91 and certain scavenger receptors. HSP-CD91 binding on immune cells can assist in DC maturation, secretion of cytokines and Th cell priming (Pawaria and Binder, 2011). Of note however, ecto-CRT has been observed in certain contexts to not directly mediate DC phenotypic maturation (Garg et al., 2013c). Nevertheless, ecto-CRT is an important mediator of ICD and an immunogenicity determining DAMP (Garg et al., 2013a, Obeid et al., 2007). Ecto-CRT functions as an 'eat me' signal, thereby assisting in the phagocytic uptake of dying cancer cells (Chao et al., 2010, Gardai et al., 2005, Garg et al., 2012c, Obeid et al., 2007). Moreover, ecto-CRT is capable of inciting the production of both IL6 and tumour necrosis factor (TNF) from DCs thereby facilitating Th17 polarization (Pawaria and Binder, 2011). This observation is further substantiated by a recent study which showed that increase in cancer cell-based ecto-CRT associates with an increase in DC-based IL6 production which in turn associates with increased Th1 polarization, without affecting DC-based IL1 $\beta$ or IL10 production (Garg et al., 2013c). Moreover, exogenously injected CRT has been observed to promote tumour lymphocyte infiltration and increase responsiveness to cancer immunotherapy (Wang et al., 2012). Interestingly, a clinical sample study showed that overall expression of CRT was associated with increased T cell infiltration in stage IIIB colon cancer (Peng et al., 2010). However the prognostic impact of overall CRT expression alone might be controversial (as more comprehensive studies have described it to be in fact a negative prognostic factor) and prone to cohortspecific effects (Chao et al., 2010; Fucikova et al., 2015). Hence for assessing the prognostic effect of ecto-CRT, better detection strategies (as differentiating ecto-CRT from endo-CRT is extremely difficult in tumour histopathological samples) or better cohort stratification strategies might be needed. In fact, the importance of cohort stratification strategies for this set-up was described by us recently, when we observed that the tumoral CALRhigh-phenotype was predictive of positive clinical responses to therapy with only ICD inducers like radiotherapy or paclitaxel in non-small cell lung or ovarian cancer patients, respectively (but not non-ICD inducer like topotecan in ovarian cancer or untreated non-small cell lung cancer patients) (Garg et al., in press). Additionally, we found tumoral CALR levels to positively correlate with the levels of genes relevant for phagosome maturation or processing in only the clinical ICD set-up. Interestingly, elevated levels of phosphorylated elF2 $\alpha$ 
have been shown to correlate with higher ecto-CRT on malignant myleoblasts from patients with acute myeloid leukaemia regardless of chemotherapy; and higher ecto-CRT correlated with ability of autologous T cells to secrete IFN- $\gamma$ on stimulation with blast-derived dendritic cell and better overall survival of the patients (Wemeau et al., 2010). This observation suggests that ER stress-regulated ecto-CRT is associated with the stimulation of anticancer immunity and may harbour a prognostic role in cancer patients.

Ecto-HSP90 has also been reported to be a crucial immunogenicity mediator (Spisek et al., 2007). Of note, it has been reported in an anti-B cell lymphoma DC vaccination setup, that ecto-HSP90 tends to correlate better (or at least as much as ecto-CRT) with patients responsiveness to therapy (Zappasodi et al., 2010). However, recently we observed that in the context of melanoma treatment with the chemotherapeutic, melphalan, ecto-HSP90 despite being exposed, failed to mediate immunogenicity in vivo. This shows that ecto-HSP90 might be a more context-dependent DAMP than previously recognised (Dudek-Peric et al. 2015). Unfortunately, the specific role of ecto-HSP70 during ICD remains enigmatic, however at least in a PDT setting ecto-HSP70 might favour production of nitric oxide (NO) from innate immune cells (Garg et al., 2012b, Garg et al., 2012c, Song et al., 2012).

In terms of overall ability to phagocytose dying/dead cells, an in silico analysis elucidated that CRT possesses close homologues of crucial phagocytosis-assisting motifs, whereas HSP70/90 do not (Garg et al., 2012b). This observation is substantiated by an in vitrolex vivo study showing that the presence of ecto-CRT correlates better with increase in phagocytosis than either ecto-HSP70 or ecto-HSP90 (Fucikova et al., 2011).

\section{Secretion or release of nucleotides and/or release of nucleic acids}

Active secretion of the nucleotide, adenosine triphosphate (ATP) (Elliott etal., 2009) and the secretion/release of nucleic acids (Kariko et al., 2004) from dying cells are essential for ICD (Ghiringhelli et al., 2009, Michaud et al., 2011) and anti-tumour immunity (Chiba et al., 2012), respectively.

Secreted ATP, is a potent short-range 'find me' signal (Elliott et al., 2009), that can bind ionotropic $\left(P_{2} X\right)$ as well as metabotropic $\left(\mathrm{P}_{2} \mathrm{Y}\right)$ purinergic receptors (Elliott et al., 2009, Ghiringhelli et al., 2009). Secreted ATP has also been observed to help in DC activation (Ghiringhelli et al., 2009). During ICD, secreted ATP has been reported to bind to the $\mathrm{P}_{2} \mathrm{X}_{7}$ receptors, causing activation of the NLRP3 inflammasome (Ghiringhelli et al., 2009), which in turn mediates caspase-1-mediated processing and secretion of $\mathrm{IL}-1 \beta$, a crucial cytokine in the stimulation of antitumor immunity (Ghiringhelli et al., 2009). ICD-based secreted ATP has also been reported to mediate intratumoural recruitment and differentiation of antigen presenting CD11 $c^{+} C D 11 b^{+} L y 6 c^{\text {hi }}$ cells (Ma et al., 2013). Interestingly, it has been observed recently that extracellular ATP in a tissue context can reduce $\mathrm{T}$ cell mobility thereby allowing better tissue scanning by T cells (Wang et al., 2014); however, the implications of this observation for ICD are not clear yet. It is noteworthy that, beyond ATP, secretion of uric acid (UA) (Behrens et al., 2008) can also activate the NALP3 inflammasome (Martinon et al., 2006). However, the association between UA and apoptosis has not been established yet (Behrens et al., 2008). It would be interesting to study the impact of UA on cancer immunotherapy since increased UA production has been found to mediate tumour immune rejection ( $\mathrm{Hu}$ et al., 2004).

Intriguingly, it has been recently observed that release of nucleic acids, like DNA, as DAMPs from dying cells following chemotherapy can efficiently instigate an antigen-specific anticancer immune response (Chiba et al., 2012). However, whether these kind of responses or other such end-stage degradation products e.g. mitochondrial DNA and N-formyl peptides (Krysko et al., 2011), are also crucial for ICD remains an enigmatic question.

\section{Secretion or release of endogenous Toll-like receptor (TLR)- agonists}

Release of endogenous ligands binding to TLR4 has been found to be critical for ICD (Garrido et al., 2011). Cancer cells are capable of releasing various endogenous TLR4-agonists like HSP60, HSP70, HSP96, HMGB1 and $\beta$-defensin 2 (Apetoh et al., 2007b). However in the context of chemotherapy-induced ICD only passively released high-mobility group box 1 (HMGB1) protein was detected (Apetoh et al., 2007b, Krysko et al., 2012).

During ICD, released HMGB1 binds toll-like receptor (TLR)-4 on DCs and, on one hand, activates production of pro-inflammatory cytokines yet on the other hand assists in proper antigen-presentation (Apetoh et al., 2007b, Kroemer et al., 2013). Interestingly, extracellular HMGB1 has also been found to suppress the activity of the immunosuppressive Treg cells (Zhu et al., 2011).

However, there are several contradictory observations regarding the role of HMGB1 in tumourigenesis; because HMGB1 can exhibit a redox-dependent switch in functionality or exert effects on other stromal cells (e.g. endothelial cells) rather than specific effects on immune cells, thereby making it hard to draw steadfast conclusions (Jube et al., 2012, Palumbo et al., 2004). It should be noted however that, HMGB1 is not the only endogenous TLR4agonist that can be released by cancer cells undergoing ICD. For instance, human bladder carcinoma cells undergoing ICD induced by Hyp-PDT were observed to release HSP70 and HSP90 (Garg et al., 2013c, Garg et al., 2012c). Interestingly, it has been observed that extracellular HSP90 can suppress the activity of the immunosuppressive cytokine, TGF- $\beta$ (Suzuki and Kulkarni, 2010).

\section{Down-regulation of CD47: a determinant or a bystander to ICD?}

In the context of ICD, ecto-CRT and in certain extended contexts ecto-HSP90 and/or ecto-HSP70, can together breach the phagocytic barrier and increase the susceptibility of dying/dead cancer cells to opsonisation by the mononuclear phagocyte system (MPS). The phagocytic barrier, in general, is maintained by a balance between "eat me" and "don't eat me" signals (Chao et al., Gardai et al., 2005, Gregory and Brown, 2005). In normal conditions, cells possess higher "don't eat me" signals and thus maintain a phagocytic barrier - a strategy utilized by many tumour cells by up regulating the prototypical "don't eat me" signal, CD47 (Chao et al., Gardai et al., 2005, Gregory and Brown, 2005).

However, it has been reported that in the context of general apoptosis, cells tend to "loose" their CD47 levels which in the context of ICD can be paralleled by increased ecto-CRT thereby allowing phagocytic access to MPS (Johansen and Brown, 2007). Thus, suppression of the 'don't eat me' signal is crucial for ectoCRT to act as an 'eat me' signal (Chao et al., Gardai et al., 2005, Gregory and Brown, 2005). However, as far as ICD is concerned, it is not yet clear whether CD47 suppression plays a direct role in regulating the immunogenicity of dying cells or it is just a bystander 
effect. Only Hyp-PDT based ICD has been reported so far to be associated with early loss of CD47 levels (Garg et al., 2012c) however the effect of this on phagocytosis was not investigated.

\section{Danger signalling pathways: mechanistic determinant of immunogenic cell death}

The ability of ICD-inducing therapies to cause emission of DAMPs associates with their capability of activating danger signalling in the stressed or dying cancer cells. During ICD, the emission of DAMPs by the stressed or dying cells occurs in spatiotemporally-defined fashion, largely governed by the activation of danger signalling pathways, during which stressed/dying cells surface expose CRT in the pre-apoptotic phase (e.g. before phosphatidylserine externalization), actively secrete ATP (either during pre-apoptotic stage or during the blebbing phase) and ultimately release HMGB1, post-apoptotically (e.g. during secondary necrosis).

Evidence from recent biochemical and cellular studies have validated the pivotal role of endoplasmic reticulum (ER) stress responses; either coupled to the concurrent production of ROS (e.g. for most Type I ICD inducers like chemotherapy), or nurtured by the on-target generation of ROS at the ER (e.g. for Type II ICD inducers like Hyp-PDT), for the extracellular trafficking of DAMPs. The requirement for the co-existence of threshold levels of ROS and ER stress for the activation of the danger signalling machinery eliciting ICD, has been established in different studies (Ghiringhelli et al., 2009, Panaretakis et al., 2009), which demonstrated that the immunogenicity of the dying cells is severely compromised in the presence of anti-oxidants or in the absence of a robust ER stress response. Thus, cisplatin, a genotoxic agent that induces changes in redox metabolism but fails to induce ER stress, was found to evoke ICD only in combination with thapsigargin or tunicamycin (Martins et al., 2011). Similarly, melphalan, an anti-melanoma chemotherapeutic was unable to induce threshold levels of ROSbased ER stress necessary for ecto-CRT induction, a defect that was corrected by combining with only thapsigargin but not certain other ER stressors (Dudek-Peric et al., 2015).

It should be mentioned that although ecto-CRT may also occur in apoptotically dying cells as a result of general exposure of ER chaperones and ER and Golgi membranes on the cell surface (Krysko et al., 2012), during ICD, surface exposure of CRT is an active process that precedes the morphological signs of apoptosis. Elegant studies have shown that CRT exposure in response to anthracyclines, like doxorubicin and mitoxanthrone, requires cotranslocation of ERp57 and relies on a complex pathway consisting of the sequential activation of three signalling modules: (a) an ER stress-ROS module consisting of the activation of the PERKelF2 $\alpha$ axis; (b) an apoptotic module, reliant on the pre-apoptotic caspase-8-mediated cleavage of BAP31 and regulated by BAX/ $\mathrm{BAK}$ and $\mathrm{Ca}^{2+}$ signals; and (c) a SNARE-dependent, ER-to-Golgi anterograde transport (Panaretakis et al., 2009). Furthermore, a systematic comparison of the molecular effectors of the DAMP trafficking mechanisms in dying cancer cells in response to anthracyclines or Hyp-PDT, revealed that ecto-CRT following HypPDT occurs independently of ERp57 co-translocation and relies distinctively on PERK-regulated secretory pathway, BAX/BAK and an intact ER-to-Golgi anterograde transport, whereas, in contrast to anthracyclines, is independent of elF2 $\alpha$ phosphorylation, $\mathrm{Ca}^{2+}$ and caspase-8, or caspase signalling in general (Garg et al., 2012b, Garg et al., 2012c). This study revealed also that both ICD inducers require a PI3K-mediated distal secretory pathway to emit ecto-CRT (Garg et al., 2012c). Importantly, in the case of Hyp-PDT, active ATP secretion occurred concomitantly to ecto-CRT and was governed by similar PERK-regulated proximal secretory pathway and PI3K-dependent exocytosis mechanisms (Garg et al., 2012c). This study thus unravelled that the activation of a unique danger signalling pathway, depending largely on house-keeping processes, is responsible for the simultaneous and coordinated emission of two DAMPs in this ICD scenario and highlighted the dispensability of certain auxiliary molecular effectors, like elF2a and caspases, for the emission of DAMPs after Hyp-PDT.

This finding is also interesting considering that the active release of ATP from dying cells in response to UV, anti-CD95/FAS therapy (Elliott et al., 2009) and chemotherapy (Martins et al., 2014) usually occurs during the early-intermediate phases of apoptosis (e.g. blebbing phase) and involves pannexin-1-dependent (Elliott et al., 2009) or autophagy-dependent ATP secretion pathways (Martins et al., 2014), which are both reliant on caspase activity. In the case of mitoxanthrone and oxaliplatin, ATP release from dying cancer cells was shown to be inhibited by the knockdown of essential autophagy-related genes (ATG5, ATG7 and BECN1), such that reducing extracellular ATP levels during ICD compromised tumour-specific immune response in vivo (Michaud et al., 2011). However, the role of autophagy in the modulation of danger signalling during ICD appears to be also largely context-dependent. While chemotherapy-induced ICD exploits the trafficking properties of the autophagy machinery to mobilize ATP, but does not affect ecto-CRT (Michaud et al., 2011); autophagy during Hyp-PDT acts apically as a cytoprotective degradation mechanism that assists in the removal of the excessive amount of oxidized proteins (including ER chaperones such as CRT) generated by Hyp-PDT, thereby reducing ecto-CRT, without affecting the trafficking and release of ATP (Garg et al., 2013a, Garg et al., 2013c, Martin et al., 2015). Moreover, recently it was also observed that NDV-induced ICD is not associated with the release of extracellular ATP despite the induction of autophagy in NDV-treated cancer cells (Koks et al., 2015). These latter observations reveal the overall complexity of ATP secretion pathways and disapprove a proportional relationship between autophagy induction and ATP secretion in all ICD contexts.

Hence, all together these studies indicate that the danger signalling underlying the mobilization of crucial DAMPs, like ecto-CRT and secreted ATP, in response to anticancer therapy is subjected, at least in part, to the type of the cell death stimulus and the molecular nature and mediators of the danger signalling it instigates. This notion needs to be considered in future clinical studies when anticancer agents may be combined with modulators of cell stress pathways, such as autophagy, which are clinically available.

In spite of the substantial mechanistic information acquired on the pathways evoking danger signalling, certain gaps-in-theknowledge still need to be filled. For example, it still remains enigmatic why concomitant ER stress and ROS production are so intricately central for the activation of danger signalling during ICD. While the oxidative module may be required to drive oxidation-mediated changes in the structures/epitopes of certain endogenous biomolecules, a process that might shift their status from a "self" to a more "non-self or danger evoking" one, thereby increasing their perception by the immune cells (Chang et al., 2004, Chiang et al., 2008), it is peculiar that out of the three ER 
stress sensors, i.e. PERK, IRE1 and ATF6, only the activation or presence of PERK is critical for DAMP emission. One intriguing possibility is that PERK, besides playing an essential role in physiological and pathological secretion (Garg etal., 2012c, Gupta etal., 2010), is a key mediator of the antiviral response caused by loss of proteostasis and ER stress upon viral infection (Zhang et al., 2014). Consistent with this view, emerging data suggest that ICD shares key danger signalling pathways with viral infection (Garg et al., 2014). The observation that ICD can be instigated by certain oncolytic viruses (Vacchelli et al., 2013), supports this notion.

Interestingly, a recent elegant study reported that during ER stress, misfolded glycosylphosphatidylinositol-anchored proteins tend to engage an ER escape mechanism, involving the ER-export receptor Tmp21, through which they enter the secretory pathway and are temporally exported to the cell surface (Satpute-Krishnan et al., 2014). However, whether this phenomenon plays any role in the ER stress-induced DAMPs emission needs further confirmation. Additionally, a recent study revealed the contribution of a phylogenetically conserved stress pathway reliant on chemokine (C-X-C motif) ligand 8 (CXCL8), also known as IL-8, to the exposure of chemotherapy-induced ecto-CRT (Sukkurwala et al., 2014b). This suggests that the efficient redistribution of CRT on the surface of dying cells may be facilitated or amplified by soluble factors acting in an autocrine (or paracrine) manner. However, we have recently observed that Hyp-PDT treatment does not induce IL-8 secretion in cancer cells thereby making IL-8 dispensable for Hyp-PDT induced ecto-CRT (Dudek-Peric et al., 2015). This further shows that danger signalling pathways cannot be generalized to all ICD inducers based on investigations done for a particular class of therapies (e.g. chemotherapy); such that while some 'core' danger signalling modules might be shared amongst all ICD inducers (e.g. PERK activity) yet certain other modules might be more 'private' for each inducer (e.g. caspase-8 for chemotherapy) (Garg et al., 2012a).

\section{Immunological and operational determinants of im- munogenic cell death}

\section{Innate and adaptive immune system stimulation}

DAMPs associated with ICD exert strong immunostimulatory effects upon binding to their respective receptors on immune cells, like pattern recognition receptors, scavenging receptors or purinergic receptors expressed by immune cells (Zitvogel et al., 2010). DAMPs and other modifications brought about by the ICD inducers helps them in establishing a productive interface between dying/dead cancer cells and the immune system. Research has clearly shown that on various molecular and certain immunological levels, Type II ICD inducers might have some advantages over Type I ICD inducers e.g. fast kinetics of DAMPs mobilization leading to a highly DAMP-enriched pre-apoptotic stage, associated with a highly productive interface between dying cancer cells and dendritic cells (DCs), devoid of immunosuppressive molecules like IL10, and strong tumour microenvironment "resetting" ability (Garg et al., 2014, Koks et al., 2015, Krysko et al., 2012).

The interface between cancer cells undergoing ICD and the immune system has been analyzed in details, for both mice as well as human settings, for only a hand full of ICD inducers which include mainly anthracyclines or oxaliplatin, radiotherapy and Hyp-PDT. These studies have shown that, cancer cells undergoing ICD are capable of attracting DCs and certain specific DC subsets mainly via secreted ATP (but possible also via HMGB1). Once attracted, DCs interacting with cancer cells experiencing ICD undergo efficient stimulation, "differentiating" into fully mature immunogenic DCs overexpressing various surface maturation markers like CD80, CD83, CD86 and MHC-II accompanied by production of immunostimulatory cytokines or factors like IL $1 \beta$, nitric oxide, IL12p70, IL6 in absence of or decrease occurrence of IL10 (at least for Hyp-PDT) (Apetoh et al., 2007a, Casares et al., 2005, Fucikova et al., 2011, Garg et al., 2013c, Garg et al., 2012c, Obeid et al., 2007). This APC/DC-level activations generally proceed into two sequential phases i.e. recruitment of $T$ cells followed by their activation into IL-17-secreting $\gamma \delta$ T cells, $\alpha \beta$ Th1 cells (IFN- $\gamma$ secreting $\mathrm{CD}^{+} \mathrm{T}$ cells) and $\alpha \beta$ cytotoxic T cells (IFN- $\gamma$ secreting CD8+ T cells) (Fucikova et al., 2011, Garg et al., 2013c, Ma et al., 2011, Mattarollo et al., 2011, Michaud et al., 2011). The latter are not only capable of mediating direct antitumourigenic effects but also underlie the establishment of host-protective immunological memory. Of note, comprehensive studies on the effect of ICD on macrophages, Th17 cells and Treg cells are still lacking and require attention in future. Moreover, most of the above results are derived either from ex vivo immune cell co-culture experiments or analysis of heterotropic subcutaneous tumours. In future there is an urgent need to extend these studies to either spontaneous tumour models or orthotopic tumour models.

\section{Tumour-rejecting immunity in a vaccination context}

Almost a decade-long list of published research has characterized various molecular, mechanistic and immunological determinants of ICD; however, the gold-standard approach to evaluate the ability of a specific agent or modality to elicit bona fide ICD still relies on vaccination assays showing tumour-rejecting capabilities of the immunized host (Casares et al., 2005, Kroemer et al., 2013). In this setting, the cancer cells are treated in vitro with the drug/agent/modality/therapy under consideration and then injected either intraperitoneally or subcutaneously/intradermally into the flank of immunocompetent syngeneic rodents, followed by a re-challenge with living cells of the same cancer type into the opposite flank or another site-of-choice for the tumour. The proportion of rodents that resist such subcutaneous tumours reveal the degree of immunogenicity of cell death for the therapy under consideration (in case of prototypical ICD inducers like anthracyclines or Hyp-PDT, this happens for $90-70 \%$ of mice, although strain-to-strain, cancer type-to-cancer type and setupto-setup differences can exist) (Garg et al., 2012c, Menger et al., 2012, Obeid et al., 2007).

\section{Conclusion and future perspective}

There are several challenges ahead of which four stand-out. Firstly, ICD needs to be translated to advanced rodent models. Secondly, rodent models exhibiting naturally-occurring defects in ICD need to be characterized in order to identify intrinsic naturaldefects that may "de-rail" ICD. The only scenario so far characterized in this direction is defects on the level of TLR4 mutations however cancer cell-level defects remain elusive. Thirdly, there is an impending need to differentiate between false positive and bona fide ICD inducers. Drugs or modalities that are characterized to only induce ICD-associated DAMPs (i.e. molecular determinant) 
in vitro but not ICD-associated immunological determinants (ex vivo or in vivo) and/or its operational determinant (i.e. anti-cancer vaccination effect, in vivo) cannot reliably be categorized as bona fide ICD inducers. This is especially applicable to agents that do not induce proper spatiotemporally defined DAMPs emission pattern associated with ICD (i.e. pre-apoptotic ecto-CRT/ecto-HSP90, pre- or early-apoptotic secreted ATP and mid- or post-apoptotic release of HMGB1/HSP70/HMGB1). In such cases it is hard to differentiate between the bystander presence of these DAMPs and their actual ICD-associated functions. Of note, ecto-CRT is the most important ICD-DAMP since its presence is universal to all ICD inducers while ATP or HMGB1 may or may not be present in certain ICD contexts e.g. despite autophagy induction, Newcastle disease virus-induced ICD is devoid of secreted ATP (Koks et al., 2015); similarly, in the human bladder cancer context, the bona fide ICD inducer, Hyp-PDT is not able to induce HMGB1 release (Garg et al., 2013c, Garg et al., 2012c). Thus, only analysis of molecular determinants is not reliable for ICD characterization. To this end, the analysis of ICD-DAMPs should be considered secondary to in vivo immunological or vaccination analysis and/ or ex vivo immunological analysis (involving both DCs and T cells), in order to conclude that a given drug/modality is an ICD inducer. These rigorous standards, if maintained, would allow proper characterization of new ICD inducers while eliminating the possibility of false positives. Last but not least, there is an urgent need to characterize the impact of ICD in the clinic and to identify ICD-related biomarkers capable of predicting the likelihood of a patient to respond to anticancer therapies that engage the host's immune system.

\section{Acknowledgements}

This work was supported by GOA/11/2009 grant of the KU Leuven, Federal Grant under the IAP7/32 of the Belgian Science Policy Office and FWO grant G0584.12 to Patrizia Agostinis. Abhishek D. Garg is supported by the FWO Postdoctoral Fellowship.

\section{References}

ADKINS, I., FUCIKOVA, J., GARG, A.D., AGOSTINIS, P. and SPISEK, R. (2014). Physical modalities inducing immunogenic tumor cell death for cancer immunotherapy. Oncoimmunology 3: e968434.

APETOH, L., GHIRINGHELLI, F., TESNIERE,A., CRIOLLO, A., ORTIZ, C., LIDEREAU, R., MARIETTE, C., CHAPUT, N., MIRA, J.P., DELALOGE, S. et al., (2007a). The interaction between HMGB1 and TLR4 dictates the outcome of anticancer chemotherapy and radiotherapy. Immunol Rev 220: 47-59.

APETOH, L., GHIRINGHELLI, F., TESNIERE, A., OBEID, M., ORTIZ, C., CRIOLLO, A., MIGNOT, G., MAIURI, M.C., ULLRICH, E., SAULNIER, P. et al., (2007b). Toll-like receptor 4-dependent contribution of the immune system to anticancer chemotherapy and radiotherapy. Nat Med 13: 1050-1059.

BEHRENS, M.D., WAGNER, W.M., KRCO, C.J., ERSKINE, C.L., KALLI, K.R., KREMPSKI, J., GAD, E.A., DISIS, M.L. and KNUTSON, K.L. (2008). The endogenous danger signal, crystalline uric acid, signals for enhanced antibody immunity. Blood 111: 1472-1479.

BOON, T. and KELLERMANN, O. (1977). Rejection by syngeneic mice of cell variants obtained by mutagenesis of a malignant teratocarcinoma cell line. Proc Natl Acad Sci USA 74: 272-275.

BOON, T. and VAN PEL, A. (1978). Teratocarcinoma cell variants rejected by syngeneic mice: protection of mice immunized with these variants against other variants and against the original malignant cell line. Proc Natl Acad Sci USA 75: 1519-1523.

BUGAUT, H., BRUCHARD, M., BERGER, H., DERANGERE, V., ODOUL, L., EUVRARD, R., LADOIRE, S., CHALMIN, F., VEGRAN, F., REBE, C. et al., (2013). Bleomycin exerts ambivalent antitumor immune effect by triggering both immu- nogenic cell death and proliferation of regulatory T cells. PLoS One 8: e65181.

CASARES, N., PEQUIGNOT, M.O., TESNIERE, A., GHIRINGHELLI, F., ROUX, S., CHAPUT, N., SCHMITT, E., HAMAI, A., HERVAS-STUBBS, S., OBEID, M. et al., (2005). Caspase-dependent immunogenicity of doxorubicin-induced tumor cell death. J Exp Med 202: 1691-1701.

CHANG, M.K., BINDER, C.J., MILLER, Y.I., SUBBANAGOUNDER, G., SILVERMAN, G.J., BERLINER, J.A. and WITZTUM, J.L. (2004). Apoptotic cells with oxidationspecific epitopes are immunogenic and proinflammatory. J Exp Med200: 1359-1370.

CHAO, M.P., JAISWAL, S., WEISSMAN-TSUKAMOTO, R., ALIZADEH, A.A., GENTLES, A.J., VOLKMER, J., WEISKOPF, K., WILLINGHAM, S.B., RAVEH, T., PARK, C.Y. et al., (2010). Calreticulin is the dominant pro-phagocytic signal on multiple human cancers and is counterbalanced by CD47. Sci Trans/Med2:63ra94.

CHEN, H.M., WANG, P.H., CHEN, S.S., WEN, C.C., CHEN, Y.H., YANG, W.C. and YANG, N.S. (2012). Shikonin induces immunogenic cell death in tumor cells and enhances dendritic cell-based cancer vaccine. Cancer Immunol Immunother 61: 1989-2002.

CHIANG, C.L., LEDERMANN, J.A., AITKENS, E., BENJAMIN, E., KATZ, D.R. and CHAIN, B.M. (2008). Oxidation of ovarian epithelial cancer cells by hypochlorous acid enhances immunogenicity and stimulates $T$ cells that recognize autologous primary tumor. Clin Cancer Res 14: 4898-4907.

CHIBA, S., BAGHDADI, M., AKIBA, H., YOSHIYAMA, H., KINOSHITA, I., DOSAKAAKITA, H., FUJIOKA, Y., OHBA, Y., GORMAN, J.V., COLGAN, J.D. et al., (2012). Tumor-infiltrating DCs suppress nucleic acid-mediated innate immune responses through interactions between the receptor TIM-3 and the alarmin HMGB1. Nat Immunol 13: 832-842.

CIAMPRICOTTI, M., HAU, C.S., DOORNEBAL, C.W., JONKERS, J. and DE VISSER, K.E. (2012). Chemotherapy response of spontaneous mammary tumors is independent of the adaptive immune system. Nat Med 18: 344-346.

COULIE, P.G., VAN DEN EYNDE, B.J., VAN DER BRUGGEN, P. and BOON, T. (2014). Tumour antigens recognized by $T$ lymphocytes: at the core of cancer immunotherapy. Nat Rev Cancer 14: 135-146.

DE PLAEN, E., LURQUIN, C., VAN PEL, A., MARIAME, B., SZIKORA, J.P., WOLFEL, T., SIBILLE, C., CHOMEZ, P. and BOON, T. (1988). Immunogenic (tum-) variants of mouse tumor P815: cloning of the gene of tum- antigen P91A and identification of the tum- mutation. Proc Natl Acad Sci USA 85: 2274-2278.

DUDEK, A.M., GARG, A.D., KRYSKO, D.V., DE RUYSSCHER, D. and AGOSTINIS, P. (2013). Inducers of immunogenic cancer cell death. Cytokine Growth Factor Rev 24: 319-333.

DUDEK-PERIC AM, FERREIRA GB, MUCHOWICZ A, WOUTERS J, PRADA N, MARTIN S, et al. (2015). Antitumor immunity triggered by melphalan is potentiated by melanoma cell surface-associated calreticulin. Cancer Res. 75: 1603-1614.

DUEWELL, P., STEGER, A., LOHR, H., BOURHIS, H., HOELZ, H., KIRCHLEITNER, S.V., STIEG, M.R., GRASSMANN, S., KOBOLD, S., SIVEKE, J.T. et al., (2014). RIG-I-like helicases induce immunogenic cell death of pancreatic cancer cells and sensitize tumors toward killing by CD8 T cells. Cell Death Differ 21: 1825-1837.

DUNN, G.P., BRUCE, A.T., IKEDA, H., OLD, L.J. and SCHREIBER, R.D. (2002). Cancer immunoediting: from immunosurveillance to tumor escape. Nat Immunol 3: 991-998.

ELLIOTT, M.R., CHEKENI, F.B., TRAMPONT, P.C., LAZAROWSKI, E.R., KADL, A., WALK, S.F., PARK, D., WOODSON, R.I., OSTANKOVICH, M., SHARMA, P. et al., (2009). Nucleotides released by apoptotic cells act as a find-me signal to promote phagocytic clearance. Nature 461: 282-286.

FUCIKOVA, J., KRALIKOVA, P., FIALOVA, A., BRTNICKY, T., ROB, L., BARTUNKOVA, J. and SPISEK, R. (2011). Human tumor cells killed by anthracyclines induce a tumor-specific immune response. Cancer Res 71: 4821-4833.

FUCIKOVA, J., MOSEROVA, I., TRUXOVA, I., HERMANOVA, I., VANCUROVA, I., PARTLOVA, S., FIALOVA, A., SOJKA, L., CARTRON, P.F., HOUSKA, M. et al., (2014). High hydrostatic pressure induces immunogenic cell death in human tumor cells. Int J Cancer 135: 1165-1177.

FUCIKOVA J, MOSEROVA I, URBANOVA L, BEZU L, KEPP O, CREMER I, SALEK C, STRNAD P, KROEMER G, GALLUZZI L and SPISEK R (2015). Prognostic and predictive value of DAMPs and DAMP-associated processes in cancer. Front. Immunol. 6: 402. (doi: 10.3389/fimmu.2015.00402).

GALLUZZI, L., KEPP, O. and KROEMER, G. (2012). Enlightening the impact of immunogenic cell death in photodynamic cancer therapy. EMBO J 31: 1055-1057.

GALLUZZI, L., KEPP, O. and KROEMER, G. (2013). Immunogenic cell death in 
radiation therapy. Oncoimmunology 2: e26536.

GALLUZZI, L., VACCHELLI, E., BRAVO-SAN PEDRO, J.M., BUQUE, A., SENOVILLA, L., BARACCO, E.E., BLOY, N., CASTOLDI, F., ABASTADO, J.P., AGOSTINIS, P. et al., (2014). Classification of current anticancer immunotherapies. Oncotarget 5: $12472-12508$.

GAMEIRO, S.R., JAMMEH, M.L., WATTENBERG, M.M., TSANG, K.Y., FERRONE, S. and HODGE, J.W. (2014). Radiation-induced immunogenic modulation of tumor enhances antigen processing and calreticulin exposure, resulting in enhanced T-cell killing. Oncotarget 5: 403-416.

GARDAI, S.J., MCPHILLIPS, K.A., FRASCH, S.C., JANSSEN, W.J., STAREFELDT, A., MURPHY-ULLRICH, J.E., BRATTON, D.L., OLDENBORG, P.A., MICHALAK, M. and HENSON, P.M. (2005). Cell-surface calreticulin initiates clearance of viable or apoptotic cells through trans-activation of LRP on the phagocyte. Cell123: 321-334.

GARG, A.D. and AGOSTINIS, P. (2014). ER stress, autophagy and immunogenic cell death in photodynamic therapy-induced anti-cancer immune responses. Photochem Photobiol Sci 13: 474-487.

GARG, A.D., DUDEK, A.M. and AGOSTINIS, P. (2013a). Calreticulin surface exposure is abrogated in cells lacking, chaperone-mediated autophagy-essential gene, LAMP2A. Cell Death Dis 4: e826.

GARG, A.D., DUDEK, A.M. and AGOSTINIS, P. (2013b). Cancer immunogenicity, danger signals, and DAMPs: what, when, and how? Biofactors 39: 355-367.

GARG, A.D., DUDEK, A.M., FERREIRA, G.B., VERFAILLIE, T., VANDENABEELE, P., KRYSKO, D.V., MATHIEU, C. and AGOSTINIS, P. (2013c). ROS-induced autophagy in cancer cells assists in evasion from determinants of immunogenic cell death. Autophagy 9: 1292-1307.

GARG, A.D., KRYSKO, D.V., VANDENABEELE, P. and AGOSTINIS, P. (2012a). The emergence of phox-ER stress induced immunogenic apoptosis. Oncoimmunology 1: 786-788.

GARG, A.D., KRYSKO, D.V., VANDENABEELE, P. and AGOSTINIS, P. (2012b). Hypericin-based photodynamic therapy induces surface exposure of damageassociated molecular patterns like HSP70 and calreticulin. Cancer Immunol Immunother 61: 215-221.

GARG, A.D., KRYSKO, D.V., VERFAILLIE, T., KACZMAREK, A., FERREIRA, G.B., MARYSAEL, T., RUBIO, N., FIRCZUK, M., MATHIEU, C., ROEBROEK, A.J. et al., (2012c). A novel pathway combining calreticulin exposure and ATP secretion in immunogenic cancer cell death. EMBO J 31: 1062-1079.

GARG, A.D., MARTIN, S., GOLAB, J. and AGOSTINIS, P. (2014). Danger signalling during cancer cell death: origins, plasticity and regulation. Cell Death Differ21:26-38.

GARRIDO, G., RABASA, A., SANCHEZ, B., LOPEZ, M.V., BLANCO, R., LOPEZ, A., HERNANDEZ, D.R., PEREZ, R. and FERNANDEZ, L.E. (2011). Induction of immunogenic apoptosis by blockade of epidermal growth factor receptor activation with a specific antibody. J Immunol 187: 4954-4966.

GHIRINGHELLI, F., APETOH, L., TESNIERE, A., AYMERIC, L., MA, Y., ORTIZ, C., VERMAELEN, K., PANARETAKIS, T., MIGNOT, G., ULLRICH, E. etal., (2009). Activation of the NLRP 3 inflammasome in dendritic cells induces IL-1 beta-dependent adaptive immunity against tumors. Nat Med 15: 1170-1178.

GOPAL, U., BOHONOWYCH, J.E., LEMA-TOME, C., LIU, A., GARRETT-MAYER, E., WANG, B. and ISAACS, J.S. (2011). A novel extracellular Hsp90 mediated co-receptor function for LRP1 regulates EphA2 dependent glioblastoma cell invasion. PLoS One 6: e17649.

GREGORY, C.D. and BROWN, S.B. (2005). Apoptosis: eating sensibly. Nat Cell Biol 7: 1161-1163

GUPTA, S., MCGRATH, B. and CAVENER, D.R. (2010). PERK (EIF2AK3) regulates proinsulin trafficking and quality control in the secretory pathway. Diabetes 59 : 1937-1947.

HEWITT, H.B., BLAKE, E.R. and WALDER, A.S. (1976). A critique of the evidence for active host defence against cancer, based on personal studies of 27 murine tumours of spontaneous origin. Br J Cancer 33: 241-259.

HU, D.E., MOORE, A.M., THOMSEN, L.L. and BRINDLE, K.M. (2004). Uric acid promotes tumor immune rejection. Cancer Res 64: 5059-5062.

JOHANSEN, M.L. and BROWN, E.J. (2007). Dual regulation of SIRPalpha phosphorylation by integrins and CD47. J Biol Chem 282: 24219-24230.

JUBE, S., RIVERA, Z., BIANCHI, M.E., POWERS, A., WANG, E., PAGANO, I.S., PASS, H.I., GAUDINO, G., CARBONE, M. and YANG, H. (2012). Cancer cell secretion of the DAMP protein HMGB1 supports progression in malignant mesothelioma. Cancer Res. 72: 3290-3301.
KARIKO, K., NI, H., CAPODICI, J., LAMPHIER, M. and WEISSMAN, D. (2004). mRNA is an endogenous ligand for Toll-like receptor 3. J Biol Chem 279: 12542-12550.

KEPP, O., SENOVILLA, L., VITALE, I., VACCHELLI, E., ADJEMIAN, S., AGOSTINIS, P., APETOH, L., ARANDA, F., BARNABA, V., BLOY, N. et al., (2014). Consensus guidelines for the detection of immunogenic cell death. Oncoimmunology 3 : e955691.

KOKS, C.A., GARG, A.D., EHRHARDT, M., RIVA, M., VANDENBERK, L., BOON, L., VLEESCHOUWER, S.D., AGOSTINIS, P., GRAF, N. and VAN GOOL, S.W. (2015). Newcastle disease virotherapy induces long-term survival and tumor-specific immune memory in orthotopic glioma through the induction of immunogenic cell death. Int J Cancer 136: E313-E325.

KROEMER, G., GALLUZZI, L., KEPP, O. and ZITVOGEL, L. (2013). Immunogenic cell death in cancer therapy. Annu Rev Immunol 31: 51-72.

KRYSKO, D.V., AGOSTINIS, P., KRYSKO, O., GARG, A.D., BACHERT, C., LAMBRECHT, B.N. and VANDENABEELE, P. (2011). Emerging role of damageassociated molecular patterns derived from mitochondria in inflammation. Trends Immunol 32: 157-164.

KRYSKO, D.V., GARG, A.D., KACZMAREK, A., KRYSKO, O., AGOSTINIS, P. and VANDENABEELE, P. (2012). Immunogenic cell death and DAMPs in cancer therapy. Nat Rev Cancer 12: 860-875.

MA, Y., ADJEMIAN, S., MATTAROLLO, S.R., YAMAZAKI, T., AYMERIC, L., YANG, H. PORTELA CATANI, J.P., HANNANI, D., DURET, H., STEEGH, K. et al., (2013). Anticancer chemotherapy-induced intratumoral recruitment and differentiation of antigen-presenting cells. Immunity 38: 729-741.

MA, Y., AYMERIC, L., LOCHER, C., MATTAROLLO, S.R., DELAHAYE, N.F., PEREIRA, P., BOUCONTET, L., APETOH, L., GHIRINGHELLI, F., CASARES, N. etal., (2011). Contribution of IL-17-producing gamma delta $T$ cells to the efficacy of anticancer chemotherapy. J Exp Med 208: 491-503.

MARTIN, S., DUDEK-PERIC, A.M., MAES, H., GARG, A.D., GABRYSIAK, M., DEMIRSOY, S., SWINNEN, J.V. and AGOSTINIS, P. (2015). Concurrent MEK and autophagy inhibition is required to restore cell death associated danger-signalling in Vemurafenib-resistant melanoma cells. Biochem Pharmacol 93: 290-304.

MARTINON, F., PETRILLI, V., MAYOR, A., TARDIVEL, A. and TSCHOPP, J. (2006). Gout-associated uric acid crystals activate the NALP3 inflammasome. Nature 440: 237-241.

MARTINS, I., KEPP, O., SCHLEMMER, F., ADJEMIAN, S., TAILLER, M., SHEN, S., MICHAUD, M., MENGER, L., GDOURA, A., TAJEDDINE, N. etal., (2011). Restoration of the immunogenicity of cisplatin-induced cancer cell death by endoplasmic reticulum stress. Oncogene 30: 1147-1158.

MARTINS, I., WANG, Y., MICHAUD, M., MA, Y., SUKKURWALA, A.Q., SHEN, S., KEPP, O., METIVIER, D., GALLUZZI, L., PERFETTINI, J.L. et al., (2014). Molecular mechanisms of ATP secretion during immunogenic cell death. Cell Death Differ 21: 79-91.

MATTAROLLO, S.R., LOI, S., DURET, H., MA, Y., ZITVOGEL, L. and SMYTH, M.J. (2011). Pivotal role of innate and adaptive immunity in anthracycline chemotherapy of established tumors. Cancer Res 71: 4809-4820.

MATZINGER, P. (1994). Tolerance, danger, and the extended family. Annu Rev Immunol 12: 991-1045.

MENGER, L., VACCHELLI, E., ADJEMIAN, S., MARTINS, I., MA, Y., SHEN, S. YAMAZAKI, T., SUKKURWALA, A.Q., MICHAUD, M., MIGNOT, G. et al., (2012) Cardiac glycosides exert anticancer effects by inducing immunogenic cell death Sci Transl Med 4: 143ra99.

MICHAUD, M., MARTINS, I., SUKKURWALA, A.Q., ADJEMIAN, S., MA, Y., PELLEGATTI, P., SHEN, S., KEPP, O., SCOAZEC, M., MIGNOT, G. et al., (2011). Autophagy-dependent anticancer immune responses induced by chemotherapeutic agents in mice. Science 334: 1573-1577.

OBEID, M., TESNIERE, A., GHIRINGHELLI, F., FIMIA, G.M., APETOH, L., PERFETTINI, J.L., CASTEDO, M., MIGNOT, G., PANARETAKIS, T., CASARES, N. et al., (2007). Calreticulin exposure dictates the immunogenicity of cancer cell death. Nat Med 13: 54-61.

PALUMBO, R., SAMPAOLESI, M., DEMARCHIS, F., TONLORENZI, R., COLOMBETTI, S., MONDINO, A., COSSU, G. and BIANCHI, M.E. (2004). Extracellular HMGB1, a signal of tissue damage, induces mesoangioblast migration and proliferation. J Cell Biol 164: 441-449.

PANARETAKIS, T., KEPP, O., BROCKMEIER, U., TESNIERE, A., BJORKLUND, A.C., CHAPMAN, D.C., DURCHSCHLAG, M., JOZA, N., PIERRON, G., VAN ENDERT, P. et al., (2009). Mechanisms of pre-apoptotic calreticulin exposure in 
immunogenic cell death. EMBO J 28: 578-590.

PAWARIA, S. and BINDER, R.J. (2011). CD91-dependent programming of T-helper cell responses following heat shock protein immunization. Nat Commun 2: 521.

PENG, R.Q., CHEN, Y.B., DING, Y., ZHANG, R., ZHANG, X., YU, X.J., ZHOU, Z.W., ZENG, Y.X. and ZHANG, X.S. (2010). Expression of calreticulin is associated with infiltration of T-cells in stage IIIB colon cancer. World J Gastroenterol 16:2428-2434.

POL, J., BLOY, N., OBRIST, F., EGGERMONT, A., GALON, J., CREMER, I., ERBS, P., LIMACHER, J.-M., PREVILLE, X., ZITVOGEL, L. et al., (2014). Trial Watch: Oncolytic viruses for cancer therapy. Oncoimmunology 3: 28694.

PRADEU, T. and COOPER, E.L. (2012). The danger theory: 20 years later. Front Immunol 3: 287.

SATPUTE-KRISHNAN, P., AJINKYA, M., BHAT, S., ITAKURA, E., HEGDE, R.S. and LIPPINCOTT-SCHWARTZ, J. (2014). ER stress-induced clearance of misfolded GPI-anchored proteins via the secretory pathway. Cell 158: 522-533.

SCHIAVONI, G., SISTIGU, A., VALENTINI, M., MATTEI, F., SESTILI, P., SPADARO, F., SANCHEZ, M., LORENZI, S., D'URSO, M.T., BELARDELLI, F. et al., (2011). Cyclophosphamide synergizes with type I interferons through systemic dendritic cell reactivation and induction of immunogenic tumor apoptosis. Cancer Res 71: 768-778.

SCHILDKOPF, P., FREY, B., OTT, O.J., RUBNER, Y., MULTHOFF, G., SAUER, R., FIETKAU, R. and GAIPL, U.S. (2011). Radiation combined with hyperthermia induces HSP70-dependent maturation of dendritic cells and release of pro-inflammatory cytokines by dendritic cells and macrophages. Radiother Oncol 101: 109-115.

SENOVILLA, L., VITALE, I., MARTINS, I., TAILLER, M., PAILLERET, C., MICHAUD, M., GALLUZZI, L., ADJEMIAN, S., KEPP, O., NISO-SANTANO, M. et al., (2012). An immunosurveillance mechanism controls cancer cell ploidy. Science 337: 1678-1684.

SONG, S., ZHOU, F., CHEN, W.R. and XING, D. (2012). PDT-induced HSP70 externalization up-regulates NO production via TLR2 signal pathway in macrophages. FEBS Lett DOI: 10.1016/j.febslet.2012.11.026.

SPISEK, R., CHARALAMBOUS, A., MAZUMDER, A., VESOLE, D.H., JAGANNATH, S. and DHODAPKAR, M.V. (2007). Bortezomib enhances dendritic cell (DC)-mediated induction of immunity to human myeloma via exposure of cell surface heat shock protein 90 on dying tumor cells: therapeutic implications. Blood 109: 4839-4845.

SUKKURWALA, A.Q., ADJEMIAN, S., SENOVILLA, L., MICHAUD, M., SPAGGIARI, S., VACCHELLI, E., BARACCO, E.E., GALLUZZI, L., ZITVOGEL, L., KEPP, O. et al., (2014a). Screening of novel immunogenic cell death inducers within the $\mathrm{NCl}$ Mechanistic Diversity Set. Oncoimmunology 3: e28473.

SUKKURWALA, A.Q., MARTINS, I., WANG, Y., SCHLEMMER, F., RUCKENSTUHL, C., DURCHSCHLAG, M., MICHAUD, M., SENOVILLA, L., SISTIGU, A., MA, Y. et al., (2014b). Immunogenic calreticulin exposure occurs through a phylogenetically conserved stress pathway involving the chemokine CXCL8. Cell Death Differ 21: 59-68.

SUZUKI, S. and KULKARNI, A.B. (2010). Extracellular heat shock protein HSP9obeta secreted by MG63 osteosarcoma cells inhibits activation of latent TGF-beta1. Biochem Biophys Res Commun 398: 525-531.

VACCHELLI, E., EGGERMONT, A., SAUTES-FRIDMAN, C., GALON, J., ZITVOGEL, L., KROEMER, G. and GALLUZZI, L. (2013). Trial watch: Oncolytic viruses for cancer therapy. Oncoimmunology 2: e24612.

VAN DERBRUGGEN, P., TRAVERSARI, C., CHOMEZ, P., LURQUIN, C., DE PLAEN,
E., VAN DEN EYNDE, B., KNUTH, A. and BOON, T. (1991). A gene encoding an antigen recognized by cytolytic $\mathrm{T}$ lymphocytes on a human melanoma. Science 254: 1643-1647.

VAN PEL, A. and BOON, T. (1982). Protection against a nonimmunogenic mouse leukemia by an immunogenic variant obtained by mutagenesis. Proc Natl Acad Sci USA 79: 4718-4722.

WANG, C.M., PLOIA, C., ANSELMI, F., SARUKHAN, A. and VIOLA, A. (2014) Adenosine triphosphate acts as a paracrine signaling molecule to reduce the motility of T cells. EMBO J 33: 1354-1364.

WANG, H.T., LEE, H.I., GUO, J.H., CHEN, S.H., LIAO, Z.K., HUANG, K.W., TORNG, P.L. and HWANG, L.H. (2012). Calreticulin promotes tumor lymphocyte infiltration and enhances the antitumor effects of immunotherapy by up-regulating the endothelial expression of adhesion molecules. Int J Cancer 130: 2892-2902.

WEMEAU, M., KEPP, O., TESNIERE, A., PANARETAKIS, T., FLAMENT, C., DE BOTTON, S., ZITVOGEL, L., KROEMER, G. and CHAPUT, N. (2010). Calreticulin exposure on malignant blasts predicts a cellular anticancer immune response in patients with acute myeloid leukemia. Cell Death Dis 1: e104.

WEST, A.C., MATTAROLLO, S.R., SHORTT, J., CLUSE, L.A., CHRISTIANSEN, A.J., SMYTH, M.J. and JOHNSTONE, R.W. (2013). An intact immune system is required for the anticancer activities of histone deacetylase inhibitors. Cancer Res 73: 7265-7276.

WONG, D.Y., ONG, W.W., and ANG, W.H. (2015). Induction of Immunogenic Cell Death by Chemotherapeutic Platinum Complexes. Angew.Chem. Int.Ed. 54:6483-6487.

YANG, Y., LI, X.J., CHEN, Z., ZHU, X.X., WANG, J., ZHANG, L.B., QIANG, L., MA, Y.J., LI, Z.Y., GUO, Q.L. et al., (2012). Wogonin induced calreticulin/annexin A1 exposure dictates the immunogenicity of cancer cells in a PERK/AKT dependent manner. PLoS One 7: e50811.

YU, Z., GENG, J., ZHANG, M., ZHOU, Y., FAN, Q. and CHEN, J. (2014). Treatment of osteosarcoma with microwave thermal ablation to induce immunogenic cell death. Oncotarget 5: 6526-6539.

ZAMARIN, D., HOLMGAARD, R.B., SUBUDHI, S.K., PARK, J.S., MANSOUR, M. PALESE, P., MERGHOUB, T., WOLCHOK, J.D. and ALLISON, J.P. (2014). Localized Oncolytic Virotherapy Overcomes Systemic Tumor Resistance to Immune Checkpoint Blockade Immunotherapy. Sci. Translat. Med. 6: 226ra32.

ZAPPASODI, R., PUPA, S.M., GHEDINI, G.C., BONGARZONE, I., MAGNI, M., CABRAS, A.D., COLOMBO, M.P., CARLO-STELLA, C., GIANNI, A.M. and D NICOLA, M. (2010). Improved clinical outcome in indolent B-cell lymphoma patients vaccinated with autologous tumor cells experiencing immunogenic death. Cancer Res 70: 9062-9072.

ZHANG, H.M., DAI, H., HANSON, P.J., LI, H., GUO, H., YE, X., HEMIDA, M.G. WANG, L., TONG, Y., QIU, Y. et al., (2014). Antiviral activity of an isatin derivative via induction of PERK-Nrf2-mediated suppression of cap-independent translation. ACS Chem Biol 9: 1015-1024.

ZHU, X.M., YAO, Y.M., LIANG, H.P., XU, C.T., DONG, N., YU, Y. and SHENG, Z.Y. (2011). High mobility group box-1 protein regulate immunosuppression of regulatory T cells through toll-like receptor 4. Cytokine 54: 296-304.

ZITVOGEL, L., KEPP, O. and KROEMER, G. (2010). Decoding cell death signals in inflammation and immunity. Cell 140: 798-804.

ZITVOGEL, L., TESNIERE, A. and KROEMER, G. (2006). Cancer despite immunosurveillance: immunoselection and immunosubversion. NatRev Immuno/6:715-727. 


\section{Further Related Reading, published previously in the Int. J. Dev. Biol.}

The chemokine network in cancer - much more than directing cell movement

Hagen Kulbe, Neil R. Levinson, Fran Balkwill and Julia L. Wilson

Int. J. Dev. Biol. (2004) 48: 489-496

\section{Exosome signaling in mammary gland development and cancer}

An Hendrix and Alistair N. Hume

Int. J. Dev. Biol. (2011) 55: 879-887

Tumor-associated macrophages in breast cancer: distinct subsets, distinct functions Damya Laoui, Kiavash Movahedi, Eva Van Overmeire, Jan Van den Bossche, Elio Schouppe, Camille Mommer, Alexandros Nikolaou, Yannick Morias, Patrick De Baetselier and Jo A. Van Ginderachter

Int. J. Dev. Biol. (2011) 55: 861-867

The tumor macroenvironment and systemic regulation of breast cancer progression Zafira Castaño, Kristin Tracy and Sandra S. McAllister

Int. J. Dev. Biol. (2011) 55: 889-897

The countercurrent principle in invasion and metastasis of cancer cells. Recent insights on the roles of chemokines

Ghislain Opdenakker and Jo Van Damme

Int. J. Dev. Biol. (2004) 48: 519-527

5 yr ISI Impact Factor $(2013)=2.879$
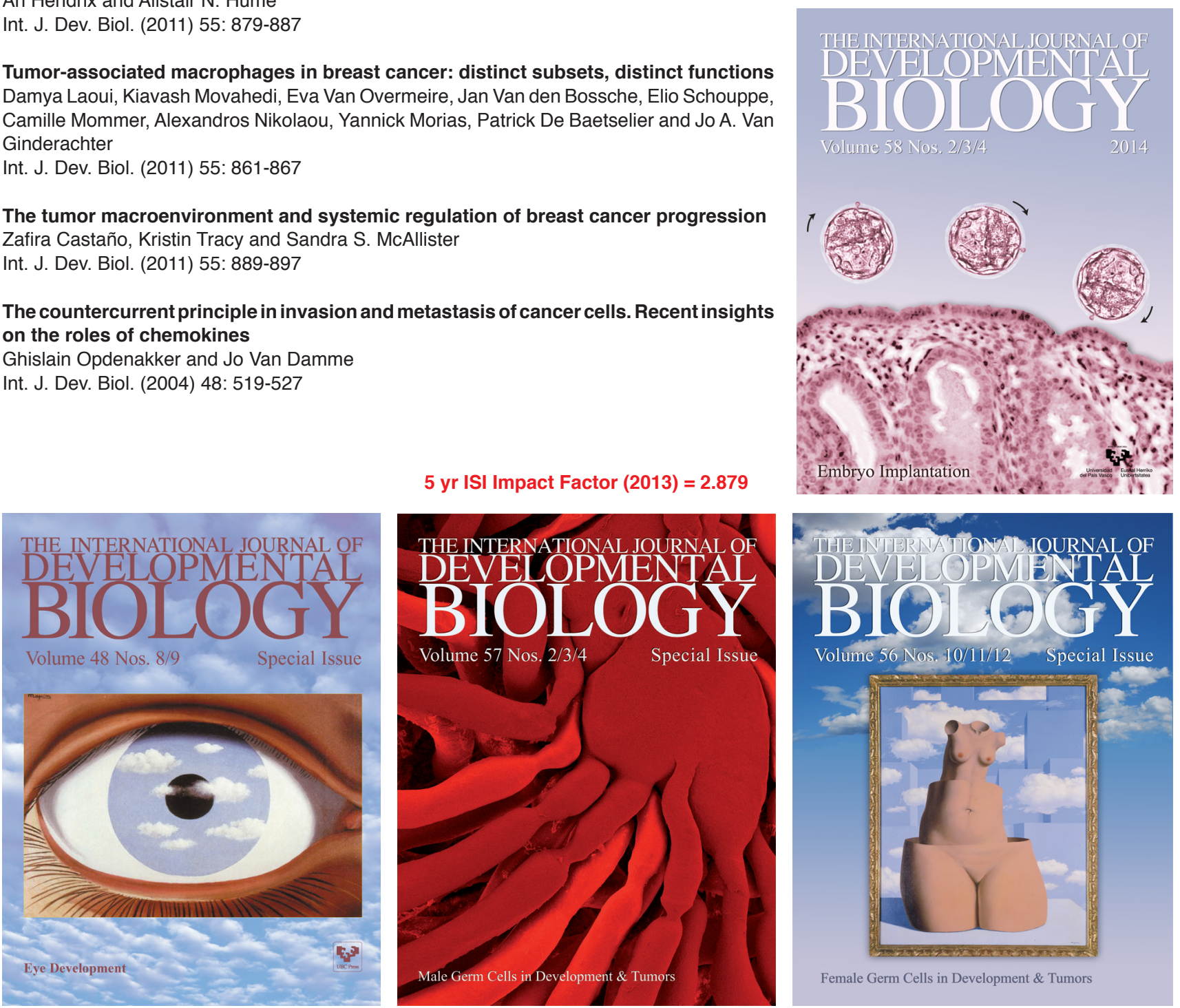

Volume 56 Nos. 10/11/12 - Special Issue

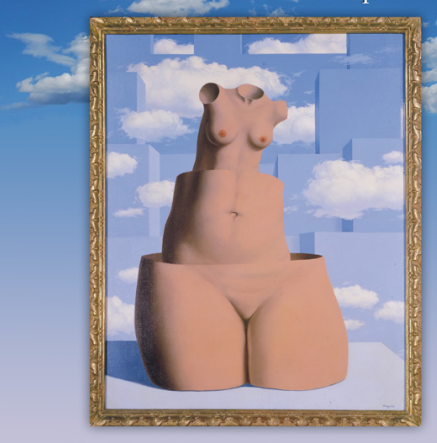

Female Germ Cells in Development \& Tumors 